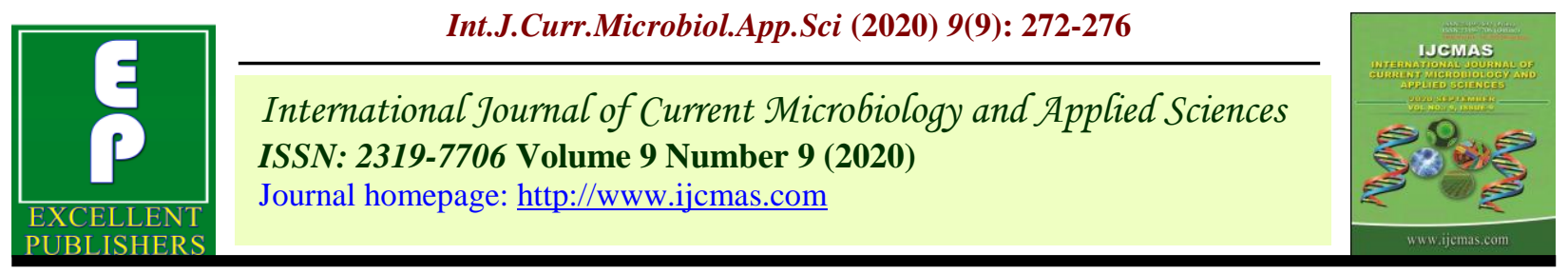

Original Research Article

https://doi.org/10.20546/ijcmas.2020.909.034

\title{
Response of Dendrobium Variety Sonia on Application of Mineral Nutrients under Protected Condition
}

\author{
Manisha Kachari ${ }^{*}$, Madhumita Choudhury Talukdar², \\ Aradhana Barooah ${ }^{3}$ and Ruby Sharma ${ }^{4}$
}

\author{
${ }^{1}$ College of Horticulture, ${ }^{2}$ Department of Horticulture, ${ }^{3}$ College of Horticulture, ${ }^{4}$ College of \\ Horticulture, Assam Agricultural University, Jorhat, Assam, India
}

*Corresponding author

\begin{abstract}
A B S T R A C T

\begin{tabular}{|l|}
\hline Ke y w o r d s \\
Orchid, Minerals, \\
Growth, Quality \\
\hline Article Info \\
\hline $\begin{array}{l}\text { Accepted: } \\
\text { 04 August } 2020 \\
\text { Available Online: } \\
\text { 10 September } 2020\end{array}$ \\
\hline
\end{tabular}

Supply of mineral nutrients in adequate amount is one of the most important factors that control growth and development of flower crops. The present experiment was conducted in the Horticulture Experimental farm, Assam Agricultural University, Jorhat, Assam during the year 2014-15 and 2015-16 using completely randomized design with thirteen numbers of treatments and three replications. The orchids were grown in coconut husk under 50 per cent shade net house in partially controlled atmosphere. The analysis revealed that foliar application of T12( RDF+ Ca 750ppm) was proved to be superior in length of pesudobulb $(28.72 \mathrm{~cm})$, Number of leaves $(6.50)$, leaf area $\left(87.23 \mathrm{~cm}^{2}\right)$, Number of spike per plant (2.17), Number of florets per spike (5.99), Size of flower $(8.5 \mathrm{~cm})$ and T11 recorded maximum in plant height $(71.67 \mathrm{~cm})$, Number of pseudobulbs $(9.0)$, length of spike $(39.0 \mathrm{~cm})$, girth of spike $(1.10 \mathrm{~cm})$, T10 recorded maximum in colour FBV to colour showing (39.10 days), showing to full bloom (8.50 days), first floret open to full bloom(6.16 days). Self life and vase life were observed maximum in T2 (RDF+ Zn 500ppm; 48.99, 41.99 days).
\end{abstract}

\section{Introduction}

The orchid, queen of flower one of the nature's most beautiful creations and well known for its diversification. This is mostly due to the adaptability of the plants to different climatic conditions and pollinators causing variation in the variety of vegetative and floral structures related to its survival. Dendrobiums are popular for potted plants and cut flowers around the world due to their wide range in flower colour, size and shape of the blooms. They bloom throughout the year, depending on environmental conditions. The long-lasting sprays of flowers remain in bloom for six to eight weeks to use as cut flowers for arrangements. Mostly Dendrobium is one of the largest of all orchid groups having 1,200 individual species that can grow in all type of climates, from hot to wet, lowlands to high-altitude, colder mountains. Dendrobium species (Khuraijam et al., 2017) consists of $85 \%$ of the total orchid cut flower of the world trade. 
Their distinctive shape, magnificent colours, and longer self and vase life have made orchids a highly profitable business all-over the world. More than 1, 00,000 hybrids are known globally and cultivated (NRCO, 2015). North-eastern states and southern states are idle place for orchid growing however the demand of orchids all over the country has increased several folds in last few years. All over the world imports and exports of flower products are increasing because of floriculture industry in India. Nutrients are very important for all plants including orchids. Soil or Terrestrial plants use their roots to absorb these nutrients. Dendobriums are epiphytes; they create their own mini nutrient by trapping wind-blown plant and animal matter, grains of soil, mineral flakes, bird droppings and other nutrients between their tangled roots where they can be absorbed by the plant from the moisture around the roots. When nutrient requirements are not sufficient or only partially sufficient the plants exhibit deficiency symptoms and if severe plant may die. Frequent application of fertilizers in low concentrations is the best way of feeding of orchids. There is necessity of estimation of its growth pattern, nutrients consumption and efficacy of different nutrient level on flower production to get quality flowers produce. Therefore present study was made to optimize the dose of mineral nutrients for quality flower production.

\section{Materials and Methods}

The experiment was carried out during the year 2014-15 and 2015-16 in the Experimental farm, Department of Horticulture, Assam Agricultural University, Jorhat, Assam. The experiment was laid out in completely randomized design with 13 numbers of treatments T1: RDF+ Zn 250ppm, T2: RDF+ Zn 500ppm, T3: RDF+ Zn 750ppm, T4: RDF+ Mg 250ppm,T5: RDF+ $\mathrm{Mg}$ 500ppm, T6: RDF+ Mg 750ppm, T7:
RDF+ B 200ppm, T8: RDF+ B 300ppm,T9: $\mathrm{RDF}+\mathrm{B}$ 400ppm, T10: RDF+ Ca 250ppm, T11: $\mathrm{RDF}+\mathrm{Ca}$ 500ppm, T12: $\mathrm{RDF}+\mathrm{Ca}$ 750ppm, T13: RDF (control) and three numbers of replications. The micronutrients which were used in experiment were Zinc sulphate, Manganese sulphate, Borax and Calcium Nitrate. The orchids were grown in partially controlled atmosphere by reducing light intensity and effective heat with 50 per cent shade net house. Growth and development of orchids varies with the potting media and environmental conditions (Kang, 1972 and Fitch, 1981).The orchids were planted in coconut husk block placed in raised bench. Coconut husk should be moist but never be mushy (Rajeevan et al., 2008). Application of fertilizers RDF @ 19:19:19 @ $2 \mathrm{~g} / \mathrm{L}$ was given after seven days interval and the mineral nutrients were sprayed at one month interval. Growth and quality parameters data were recorded and statistical analysis was done.

\section{Results and Discussion}

In orchids calcium is the building block of cell wall. It relates to the tissue firmness because of its interaction with pectin of cell wall. It absorbed nutrients through the root tips and transported to the leaves and other growing parts of the plant through xylem vessel during the transpiration process.

The nutrients are involved in several physiological processes of the plants. It activates several enzyme systems that regulate leaf and root growth (Mengel and Kirkby, 2001). From Table 1 it can be revealed that all the growth parameters plant height, number of pseudobulbs, length of pseudobulb, number of leaves, leaf area, length of spike, girth of spike were significantly different with the control ( $T$ 13). Maximum plant height and number of pseudobulb was observed in the treatment T11 (RDF+Ca500ppm) 71.67, 9.00 
respectively which was followed by T6 (RDF $+\mathrm{Mg} 750 \mathrm{ppm}) 65.60$ in plant height and T10 $(\mathrm{RDF}+\mathrm{Ca} 250 \mathrm{ppm}) 8.83$ in number of pseudobulbs. Similar findings observed with maximum length of pseudobulb, number of leaves and leaf area, was recorded 28.72, 6.50 and 87.23 in T12(RDF +Ca750ppm) followed by $25.80,5.83$ and 78.59 in T5(RDF+ Mg 500 ppm) and T6 (RDF+ Mg 750 ppm).

This result corroborates with the experimental findings of Bala et al., 2019 who reported maximum number of number of leaves per scale and bulblets per scale with calcium nitrate dose upto $20 \mathrm{~g} / \mathrm{m}^{2}$. Length and girth of spike was found to be maximum showing, 39.00 and 1.10 in T11 (RDF+ Ca 500ppm) followed by $\mathrm{T} 4$ (RDF+Mg 250ppm).The present findings are in accordance with the findings of Ruamrungsri and Inkham (2017) in Hippeastrum growth and bulb quality and Naik et al., (2013) on growth and flowering of Cymbidium hybrid.
The nitrogen in the form of nitrate is taken up and assimilated by the crop plants (Andrew et $a l ., 2013)$. Nitrogen is an essential element for growth and development processes in the plant being a component of DNA, RNA, protein and enzymes (Raven et al., 2004; Andrew et al., 2013). In orchids the flower development may be enhanced by high nitrogen uptake and assimilation. The result pertaining to the response of mineral nutrients on flowering parameters in Table 2 the minimum days to first bud visibility to colour showing, colour showing to full bloom and days to first floret open to full bloom was recorded in T10 (RDF+ Ca 250ppm; 39.10, 8.50 and 6.16) followed by $\mathrm{T} 3(\mathrm{RDF}+\mathrm{Zn}$ $750 \mathrm{ppm})$ and $\mathrm{T} 2(\mathrm{RDF}+\mathrm{Zn} 250 \mathrm{ppm})$. This might be due to calcium act as secondary messenger for flower induction (McKenzie, 1994). In case of number spike per plant, number of floret per spike, size of flower, recorded highest in treatment $\mathrm{T} 12 \mathrm{RDF}+\mathrm{Ca}$ $750 \mathrm{ppm} \quad(2.17,5.99, \quad 8.65)$ respectively followed by $\mathrm{T} 2$ and $\mathrm{T} 3$.

Table.1 Response of mineral nutrients on growth parameters

\begin{tabular}{|l|c|c|c|c|c|c|c|}
\hline Treatments & $\begin{array}{c}\text { Plant } \\
\text { Height }\end{array}$ & $\begin{array}{c}\text { No of } \\
\text { Pseudobulb }\end{array}$ & $\begin{array}{c}\text { Length of } \\
\text { Pseudobulb }\end{array}$ & $\begin{array}{c}\text { No of } \\
\text { leaves }\end{array}$ & $\begin{array}{c}\text { Leaf } \\
\text { area } \\
\text { acm }\end{array}$ & $\begin{array}{c}\text { Length } \\
\text { of spike } \\
\text { (cm) }\end{array}$ & $\begin{array}{c}\text { Girth of } \\
\text { spike } \\
\text { (cm) }\end{array}$ \\
\hline T1 & 62.95 & 6.33 & 23.41 & 4.33 & 74.92 & 35.66 & 1.04 \\
\hline T2 & 58.5 & 7.17 & 21.08 & 5.67 & 64.82 & 34.25 & 0.95 \\
\hline T3 & 63.25 & 6.66 & 21.50 & 4.50 & 73.90 & 37.33 & 0.92 \\
\hline T4 & 63.66 & 6.99 & 25.41 & 5.33 & 77.82 & 37.33 & 1.07 \\
\hline T5 & 62.00 & 6.16 & 25.80 & 5.83 & 69.24 & 33.67 & 0.98 \\
\hline T6 & 65.60 & 6.66 & 25.25 & 4.17 & 78.59 & 27.17 & 0.84 \\
\hline T7 & 54.17 & 7.16 & 25.42 & 4.17 & 62.92 & 30.00 & 0.90 \\
\hline T8 & 47.33 & 6.83 & 25.22 & 4.16 & 66.02 & 28.17 & 0.77 \\
\hline T9 & 56.64 & 7.16 & 20.83 & 4.33 & 63.13 & 33.00 & 0.97 \\
\hline T10 & 50.37 & 8.83 & 18.50 & 4.66 & 63.40 & 33.25 & 0.88 \\
\hline T11 & 71.67 & 9.00 & 19.00 & 5.50 & 67.41 & 39.00 & 1.10 \\
\hline T12 & 62.00 & 7.00 & 28.72 & 6.50 & 87.23 & 32.67 & 0.88 \\
\hline T13 & 38.91 & 5.67 & 17.33 & 2.17 & 56.30 & 25.00 & 0.40 \\
\hline SE & 7.28 & 1.59 & 6.62 & 1.49 & 15.97 & 4.66 & 0.06 \\
\hline CD(5\%) & 12.46 & 2.73 & 11.33 & 2.55 & 27.33 & 7.97 & 0.11 \\
\hline
\end{tabular}


Table.2 Response of mineral nutrients on flowering parameters

\begin{tabular}{|c|c|c|c|c|c|c|c|c|}
\hline Treatments & $\begin{array}{l}\text { FBV to } \\
\text { colour } \\
\text { showing } \\
\text { (days) }\end{array}$ & $\begin{array}{l}\text { Colour } \\
\text { showing to } \\
\text { full bloom } \\
\text { (days) }\end{array}$ & $\begin{array}{c}\text { First floret } \\
\text { open to full } \\
\text { bloom } \\
\text { (days) }\end{array}$ & $\begin{array}{c}\text { No of } \\
\text { spike } \\
\text { per } \\
\text { plant }\end{array}$ & $\begin{array}{c}\text { No of } \\
\text { floret } \\
\text { per } \\
\text { spike }\end{array}$ & $\begin{array}{c}\text { Size of } \\
\text { flower } \\
\text { (cm) }\end{array}$ & $\begin{array}{c}\text { Self life } \\
\text { (days) }\end{array}$ & $\begin{array}{c}\text { Vase life } \\
\text { (days) }\end{array}$ \\
\hline T1 & 47.47 & 12.67 & 8.5.0 & 1.33 & 4.99 & 7.95 & 34.99 & 30.83 \\
\hline T2 & 47.17 & 11.33 & 6.33 & 1.67 & 4.83 & 8.58 & 48.99 & 41.99 \\
\hline T3 & 42.83 & 9.50 & 6.50 & 1.50 & 5.67 & 8.44 & 41.67 & 31.83 \\
\hline T4 & 52.67 & 11.66 & 7.33 & 1.66 & 5.50 & 8.50 & 35.83 & 31.11 \\
\hline T5 & 53.16 & 9.66 & 8.16 & 1.33 & 5.67 & 8.47 & 34.50 & 29.67 \\
\hline T6 & 43.50 & 11.17 & 8.77 & 1.63 & 5.17 & 8.55 & 39.00 & 31.58 \\
\hline T7 & 45.33 & 14.50 & 8.17 & 1.17 & 4.17 & 7.64 & 36.33 & 29.66 \\
\hline T8 & 47.33 & 11.30 & 8.00 & 1.50 & 4.20 & 8.39 & 28.50 & 35.66 \\
\hline T9 & 44.00 & 11.10 & 8.83 & 1.50 & 3.83 & 7.47 & 27.50 & 30.33 \\
\hline T10 & 39.10 & 8.50 & 6.16 & 1.33 & 4.50 & 7.78 & 35.50 & 31.25 \\
\hline T11 & 42.16 & 10.50 & 9.46 & 1.33 & 4.83 & 8.18 & 46.66 & 40.50 \\
\hline T12 & 44.00 & 10.33 & 7.67 & 2.17 & 5.99 & 8.65 & 41.17 & 33.67 \\
\hline T13 & 61.83 & 15.10 & 12.50 & 1.17 & 3.83 & 7.08 & 26.66 & 26.83 \\
\hline SE & 7.83 & 3.02 & 2.91 & 0.45 & 0.81 & 0.65 & 3.60 & 4.02 \\
\hline $\operatorname{CD}(5 \%)$ & 13.39 & 5.17 & 4.98 & 0.77 & 1.61 & 1.12 & 6.17 & 6.87 \\
\hline
\end{tabular}

Similar results were found in the applications of 3.30 and $5.00 \mathrm{~g} / \mathrm{L} \mathrm{Ca}\left(\mathrm{NO}_{3}\right)_{2}$ increased the length of the inflorescence, floret width and floret numbers in Dendrobium orchids (Abdullakasim et al., 2016). Production of good quality attractive flowers might be due to essential nutrients, plant growth regulators, higher carbohydrate and deposition of enzymes in flower cells by the zinc that prolong the self life of flowers.

The quality flower suppresses ethylene and abscisic acid and zinc act as an activator of certain enzyme could regulate anti-oxidative activities. Therefore, it could potentially enhance the vase life by scavenging the reactive oxygen species (ROS) to adjust with oxidative damage and keep the membrane integrity (Aravind and Prasad, 2003).

Postharvest longevity of fresh cut flowers is also enhanced by calcium Reddy et al., (2016). The self life and vase were obtained maximum in $\mathrm{T} 2$ (Zn $500 \mathrm{ppm}, 48.99$ and 41.99) which was at par with T11 (Ca 500 ppm, 46.66 and 40.50).

The findings are in conformity with the observations of Tisdale et al., 1985; Bhagyalakshmamma, 1998; Karuppaiah, 2006 and Sharma et al., 2013.

In conclusion from the above results it may be conclude that foliar application $\mathrm{RDF}+\mathrm{Ca} 750$ $\mathrm{ppm}$ and $\mathrm{RDF}+\mathrm{Ca} 500 \mathrm{ppm}$ maximized the growth parameter. Whereas, flowering parameter of Dendrobium orchid, self life and vase life was maximum with foliar application of RDF+ Ca 250ppm and RDF+ Zn 500ppm.

Hence it can be recommended to apply foliar spray of calcium nitrate and zinc sulphate for a qualitative as well as quantitative flower produce. 


\section{References}

Abdullakasim, S., Meenpran, S., Imsabai, W. and Saradhuldhat, P. 2016. Pre-harvest calcium nitrate application reduces floret bud drop of dendrobium Sonia 'Earsakul'. j. ISSAAS. 22(2): 10-17.

Andrews, M., Raven, JA. and Lea, PJ. 2013. Do plants need nitrate? The mechanisms by which nitrogen form affects plants. Ann. Appl. Biol. 163:174-199.

Aravind, P. and Prasad. MNV. 2003. Zinc alleviates cadmium-induced oxidative stress in Ceratophyllum demersum L.: a free floating freshwater macrophyte. Plant physiology and biochemistry. 41(4): 391-397.

Bala, A., Sharma, P., Dhiman, SR. and Gupta, YC. 2019. Effect of Calcium Nitrate on Propagation of LA Hybrid Lilies through Scaling Int.J.Curr.Microbiol.App.Sci. 8(1): 2091-2098.

Bhagyalakshmamma, BS. 1998. Effect of micronutrients on growth, yield, quality and post harvest life of gerbera (Gerbera jamesonii Hook.) grown under cover. M.Sc. (Hort.) Thesis, University of Agricultural Sciences, Bangalore.

Fitch CM. 1981. All about orchids. Doubleday and Company Inc. New York.

Kang, LC. 1972. Orchids: Their cultivation and hybridization, Eastern universities press, Singapore.

Karuppaiah, P. 2006. Effect of spacing and nutrient levels on flower yield, carotenoid content, nutrient uptake and residual soil fertility in French marigold (Tagtes patula L.). Internat J agric Sci.2 (2): 375-376.

Khuraijam, JS., Sharma, SC. and Roy, RK. 2017. Orchids: Potential Ornamental Crop in North India. International Journal of Horticultural \& Crop Science Research. 7(1):1-8.

Mengel, K. and Kirby, E. 2001.A principles of plant nutrition. Bern: International Potash Institute.687.

McKenzie, C.B. 1994. Preliminary results of calcium and potassium uptake from foliar sprays on Sensation mango. Year Book South African Mango Growers Association. (14): 24-25.

Naik, SK, Barman, D. and Pathak, N. 2013. Response of graded levels of calcium and magnesium on growth and flowering of Cymbidium hybrid Mint Ice Glacier'. Afr. J. Agric. Res. 8(17):1767-1778.

NCRO, 2015. Vision 2015. Indian Council of Agricultural Research, New Delhi.

Rajeevan, PK., Valsalakumari, PK. and Sheela, VL.2008. Advances in the production technology of Orchids, Anthuriums and Heliconias. National Symposium on Recent Advances in Floriculture, Navsari. 33-42.

Raven, JA., Handley, LL. and Andrews, M. 2004. Global aspects of $\mathrm{C} / \mathrm{N}$ interactions determining plan-environment interactions. J. Eip. Bot. 55: 1 1-25.

Reddy, ARG. and Sarkar, MM. 2016. Studies on the effect of foliar application of calcium on post-harvest, corm and cormel production in gladiolus CV. summer sunshine, International Journal of Agriculture, Environment and Biotechnology. 89-94.

Ruamrungsri, S. and Inkham, C. 2017. Effect of calcium nitrate addition on growth and bulb quality of Hippeastrum. Acta Hortic. 167:54.

Sharma, J., Gupta, AK., Kumar, C. and Gautam, RKS. 2013. Influence of zinc, calcium and boron on vegetative and flowering parameters of gladiolus cv. Aldebran. The Bioscan. 8(4): 1153-1158

Tisdale, SL., Nelson, WL. and Beaton, ID.1985. Elements required in plant nutrition. Soil fertility and fertilizers, 4th edn.; 27: 33.

\section{How to cite this article:}

Manisha Kachari, Madhumita Choudhury Talukdar, Aradhana Barooah and Ruby Sharma. 2020. Response of Dendrobium Variety Sonia on Application of Mineral Nutrients under Protected Condition. Int.J.Curr.Microbiol.App.Sci. 9(09): 272-276.

doi: https://doi.org/10.20546/ijcmas.2020.909.034 